\title{
IAMJ
}

INTERNATIONAL

AYURVEDIC

MEDICAL JOURNAL

ISSN: 2320-5091

Impact Factor: 6.719

\section{AYURVEDIC MANAGEMENT OF KITIBHA KUSHTA W.S.R TO PSORIASIS - A SUCCESSFUL CASE STUDY}

\author{
Shwetambika ${ }^{1}$, Shaila Borannavar ${ }^{2}$, Ananta S Desai ${ }^{3}$ \\ ${ }^{1}$ PG Scholar, ${ }^{2}$ Associate Professor, ${ }^{3} \mathrm{HOD}$ and Professor, \\ Dept of PG studies in Panchakarma, GAMC, Bangalore-560009, Karnataka, India
}

Corresponding Author: shweta93bs@gmail.com

https://doi.org/10.46607/iamj3509052021

(PublishedOnline: May 2021)

Open Access

(C) International Ayurvedic Medical Journal, India 2021

Article Received:27/04/2021 - Peer Reviewed:06/05/2021 - Accepted for Publication:14/05/2021

Check for updates

\section{ABSTRACT}

Skin being the largest organ of the body is the reason behind the beauty and cause for confidence. Chronic skin conditions adversely affect one's physical, functional and emotional wellbeing, thereby causing negative impact on one's own quality of life. Due to altered lifestyle, lack of physical exercise, unhygienic, mental stress, overeating, nutrition deficiency, skin diseases are commonly observed. WHO has classified skin diseases as a Psycho-cutaneous disease. Materials \& Methods 29 year old male was diagnosed with a KitibhaKushta with a clinical feature of flaky reddish white elevated skin lesions over a B/L lower limb associated with severe itching sensation and peeling of the skin since 4 years, has been treated with classical Virechanakarma (Purgation) along with Shamanaushadhis (Oral medicines). Results: After the course of treatment the patient noticed significant relief in signs and symptoms and worth documenting. Conclusion: Kitibha Kushta though it is difficult to manage, but if proper diagnosis is made at proper time many complication can be avoided. In this case study, we found significant results in signs and symptoms with Virechana followed by Shamanoushadhi and Rasayana karma. By this we conclude that various Panchakarma procedures especially Virechana Karma and internal medicines can be the best option in its management.

Keywords: Virechana Karma, Kitibha Kushta, Psoriasis 


\section{INTRODUCTION}

Psoriasis is a long lasting, non-contagious autoimmune disease characterized by raised areas with typically red, dry, itchy scaly Patches, most commonly on Knees, Elbows, Trunk and Scalp. Psoriasis is generally thought to be a genetic disease that is triggered by environmental factors. ${ }^{1}$

According to Ayurveda all the skin manifestations are grouped under the heading of Kushta, which are divided into two category such as Mahakushta and Kshudrakushta, Kitibhakushta is one among the Kshudrakushta. In the present study Kitibhakushta has been considered as Plaque Psoriasis. All Kushtas manifest due to vitiation of Saptadhatus like Tridoshas, Twak, Rakta, Mamsa and Lasika. Kitibhakushta it is of VataKaphaja predominant condition having a Lakshanas like Shyava(black), Kina, Kharasparsha, Parusha,(Hard \& rough on touch) Rukshapidaka and Kandu (Itching). ${ }^{2}{ }^{T}$ There is no cure for Psoriasis, but various treatments can help to control the condition. In this paper combined effect of Virechana Karma with Shamanoushadhis has been shown.

\section{Case Report}

A 29 year old male patient visited to SJIIM Hospital on 19/11/20 \& was diagnosed as a Kitibhakushta with a clinical feature reddish elevated skin lesions with white scales \& severe itching sensation over anterior aspect of $\mathrm{B} / \mathrm{L}$ lower limb since $4 \mathrm{yrs}$, for the same reason previously he consulted to Dermatologist where doctor prescribed oral medications and topical creams, but patient did not find satisfactory relief. Now he consulted to SJIIM hospital for further management.

\section{Past History}

No H/O- DM AND HTN

No H/O Similar illness in a family

\section{NidananaPanchaka}

Ahara And Vihara:

- Satataatimatra, Ahitaaharasevana, Atiamla, Lavana, Katuaharasevana, Divaswapna, Dadhinitya, Masha etc

- Breakfast-idli, dosa, lemon rice, upma, puliogre

- Lunch-rice, sambar, curd

- Dinner- ragimudde, rice, sambar, curd

(Patient used take bakery items, junk foods, more of spicy foods regularly)

Purvaroopa: Vaivarnya (Discoloration), Kandu (Itching), Kothaunnati (elevated skin lesions)

Roopa: Ugrakandu, Kinakhara, Parushata (hard \& roughness) of skin

Upashaya\&Anupashaya: Increases during cold season

Table 1: Nidanas (Aharaja\&Viharaja)

\begin{tabular}{|l|l|l|}
\hline Aharaja & Viharaja & Chikitsaupachara \\
\hline Virodhi annapana (Drava snigda,guru) & $\begin{array}{l}\text { Santapaupahatsyasheetodakamatarataha, } \\
\text { diwaswapna }\end{array}$ & $\begin{array}{l}\text { Panchakarma } \\
\text { (Ayoga-VAMANA) }\end{array}$ \\
\hline $\begin{array}{l}\text { Madhu, matsya, Lakucha,Mulaka } \\
\text { Kakamachi-Satataatimatrasevana, Ajeerna }\end{array}$ & $\begin{array}{l}\text { Vipran guru gharshatam } \\
\text { Papamkarmachakurvatam }\end{array}$ & Panchakarma Upacharina \\
\hline $\begin{array}{l}\text { Chilachima+Payasa } \\
\text { Hayanka, Yavaka, Cheenaka }\end{array}$ & $\begin{array}{l}\text { Sadhu nindana, Papmabhi } \\
\text { Sadhyapraptakupita mala }\end{array}$ & \\
\hline PishtannA, Kshudranna Atisevana & Shaya, Shrama, Sntapa, Gohatya & \\
\hline
\end{tabular}

Table 2

\begin{tabular}{|l|l|}
\hline Food articles & Examples in contemporary setting \\
\hline Atilavana & Salt predominant foods like pickles, bhelpuri, papad, chips, namkeen used in excess quantity \\
\hline Atiamla & $\begin{array}{l}\text { Fermented products, pickles, bhelpuri, sour fruit juices, sauces like tomato sauce, excess intake of } \\
\text { preserved foods, curd, buttermilk, lemon juice, vinegar, alcohol, sauce, squashes. }\end{array}$
\end{tabular}


Virudhahara

Sprouted vegetables/grains with meat, milk with meat, honey with meat, black gram with meat, radish with meat, jaggery with meat, milk or honey with leafy vegetables, curd with chicken, honey heated in any form or taken with hot water, alcohol with kheer, fish with jaggery or sugar,

\section{Personal History}

- Diet-vegetarian

\section{Daily dietary routine}

- Breakfast-idli, dosa, lemon rice, upma, puliogre

- Lunch-rice, sambar, curd

- Dinner-Ragimudde, Rice, Sambar, Curd

(Patient used take bakery items, junk foods, more of spicy foods regularly)

- Habit- Tea/Coffee (3/4 times daily)

- Bowel - Regular, Once / day

- Bladder - 3-4/ day and 1-2night

- $\quad$ Sleep - Sound sleep

SampraptiGhataka

- Dosha-Vata, Pitta, Kaphaja

- Dhatu-Rasa, Rakta, Mamsa,

- Upadhatu- Twacha, lasika

- Agni - Jatharagni, Dhatwagnimandya (Rasa, Rakta, Mamsa)

- Srotas - Rasavaha, Raktavaha, Mamsavaha
- Srotodushti - Vimrgagamana /Sanga.

- Udbhavasthana- Amashaya

- Sancharastana-Sarvashareera

- Adhishtana- Twak, Rakta, Mamsa, Lasika

- Vyaktastana-Twak

- Rogamarga-Bahya

- Swabhava-Chirakari

- Sdhyaasadhyata-Yapya

On Examination of Skin

$>$ Anatomical position- Anterior aspect of $\mathrm{B} / \mathrm{L}$ lower limb

$>$ Color- Reddish with silvery scales

$>$ Distribution- symmetrical

$>$ Size- $>5 \mathrm{~cm}$

$>$ shape-irregular

$>$ Morphology-Plaque

Specific Test

- Auspitz sign- +VE

- Candle grease sign $+v e$

Table 3: Intervention

\begin{tabular}{|l|l|l|}
\hline Date & Medicine & Planned treatment \\
\hline $11 / 11 / 20$ & Chitrakadivati(4 days)1tid & Deepana,pachana \\
\hline 15 to 18 Nov & ShodhanangaSnehapana & Panchatiktakagrita \\
\hline 19.20 .21 November & Vishramakala & Pitta vardhakaraahara \\
\hline $22 / 11 / 20$ & Virechana & Trivruthlehya (50gm) \\
\hline
\end{tabular}

\section{Table4:}

\begin{tabular}{|c|c|c|}
\hline Date & Procedure & Dose \\
\hline $15 / 11 / 20$ & Snehapana & $30 \mathrm{ml}$ \\
\hline $16 / 11 / 20$ & & $70 \mathrm{ml}$ \\
\hline $17 / 11 / 20$ & & $110 \mathrm{ml}$ \\
\hline $18 / 11 / 20$ & & $190 \mathrm{ml}$ \\
\hline $19 / 11 / 20$ to $21 / 11 / 20$ & $\begin{array}{lr}\text { Abhyanga } & \text { with } \\
\text { murchitatilataila } & \& \\
\text { bhashpasweda } & \end{array}$ & \\
\hline $22 / 11 / 20$ & $\begin{array}{l}\text { Virechana with Trivruth } \\
\text { lehya }\end{array}$ & 50gmUshnajalaanupana \\
\hline Vegas & Pravarashuddhi & 21 virechanavegas (samsarjana karma advised as per the shuddhi) \\
\hline
\end{tabular}


Table 5

\begin{tabular}{|l|l|}
\hline Shamanoushadhi & Dose \\
\hline Arogyavardinivati & 1TID \\
\hline Panchatiktakashyaya & $15 \mathrm{ml}$ BD \\
\hline Sarivadivati & 1TID \\
\hline Psorolin oil & For E/A \\
\hline
\end{tabular}

Table 6

\begin{tabular}{|l|l|l|}
\hline Feature & BT & AT \\
\hline Color & Silvery & Reduced \\
\hline Type of lesion & Plaque & Absent \\
\hline Itching & Severe & Absent \\
\hline Lesion size & Larger & Decreased \\
\hline Scaling & Present & Absent \\
\hline General look & Ill & Normal \\
\hline Depression & Present & Absent \\
\hline
\end{tabular}

\section{Observation-Before Treatment}

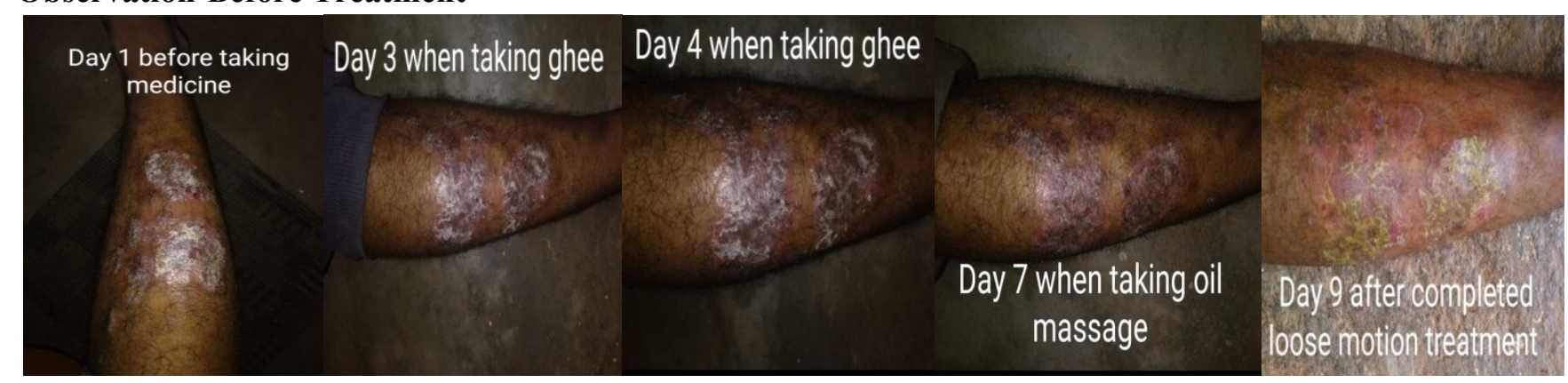

\section{After Treatment}

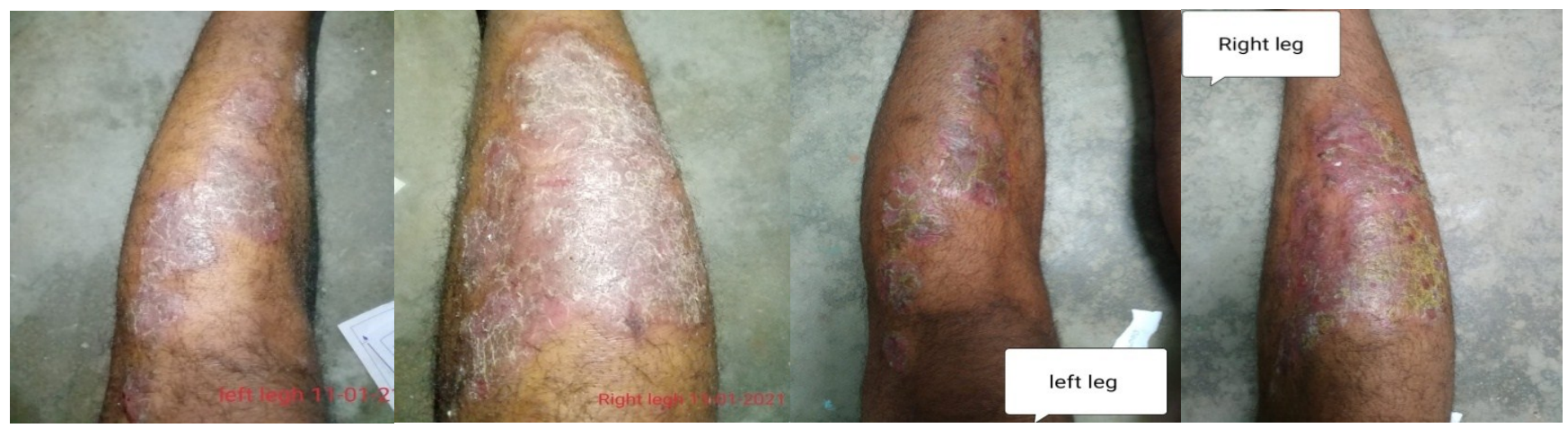

\section{DISCUSSION}

Patient had irregular diet pattern and excess Intake of curd at night time, excessive intake of pickles \& tea per day and resulting into vitiation of Pitta \& Kapha leading to KitibhaKushta. Among all Shodhana therapies Virechana is widely used procedure because of it is simple, eliminating the doshas in large quantity with less stress \& has lesser complications when compared to Vamana. Virechana is an ideal procedure for Pittaja \& Raktaja Vyadhi's which are in Ashraya Ashrayibhava \& also useful in the disorders in which pitta is associated with Kapha or DushitaKapha in Pitta sthana ${ }^{3}$.

Deepana-paachana is very essential \& mandatory before shodhana as it helps to digest the amadosha present in the koshta \& increases agni which aids in 
the digestion of large quantity of Sneha administered thereafter. Both Snehana \& Swedana help in the movement of Dosha \& Dosha Shithilikarana \& bring the Doshas from Shakha to Koshta.

As Shodhanangasnehapana "Mahatiktakagrith" is used, which is prepared with drugs having the properties like Deepana, paachana, Amapachana, Srotoshodhaka, Raktaprasadana, Raktashodhaka, Kandugna, Kushtagna, Varnya. As per the Classical reference it has special indication in Kushtavikaras. ${ }^{4}$ Here Trivruthlehya ${ }^{5}$ is used for Virechana karma as it is MruduVirechaka and it is explained to perform shodhana repeatedly. Vyavayi property of Virechanadravya is responsible for quick absorption, while VikasiGuna causes softening and loosing of bond by Dhatu Shaithilyakarana. Due to Ushna Dosha Sanghata is liquefied. Tikshnaguna of Virechanadravya produces Chedana of Dosha which are already softened due to Snehanaand Swedana so liquefied Dosha dragged to Koshta and eliminate from the body. Along with Virechana advocating Shamanaaushadhi and proper Pathya will give faster and long-lasting results. Shamanoushadhi's which are prescribed are having the property of Raktashodhaka, Kushthagnaetc. which will help in relieving the symptoms.

\section{CONCLUSION}

The prevalence of KitibhaKushta is increasing day by day. Kitibhakushta though it is difficult to manage, but if proper diagnosis is made at proper time many complication can be avoided. In this case study we found significant results in signs and symptoms with Virechana followed by Shamanoushadhi and Rasyana karma. This is one among the relapsing type of skin disease, so patient is advised to follow Pathyaapathya like Ahara, Vihara, Achara and Vichara Repeated Shodhana ${ }^{6}$ as per classics in accordance with Dosha, Kala, Agni and Desha should be administered to control the frequency of recurrence and further spread, by this we conclude that various panchakarma procedures especially virechana and internal medicines can be best option of its management.

\section{REFERENCES}

1. Institute for Health Metrics and Evaluation (IHMe) Global Burden of Disease Study 2010: Result Cause 1990-2010. Seattle: IHME; 2012

2. Agnivesh, Chikitsa Sthana 7:21 Hindi commentary by Acharya Vidyadhar Shukla and Prof Ravi Dutt Tripathi, Charakasamhita, Delhi, Chaukamba Sanskrit Prakashan; 2013.p184

3. Acharya Mukundilal Diviwedi, Panchakarma Chikitsa, Chaukamba Sanskrit Sansthanam, Varanasi, $6^{\mathrm{TH}}$ Chapter pp.-427.

4. Agnivesh, ChikitsaSthana 7:21 Hindi commentary by Acharya Vidyadhar Shukla and Prof Ravi Dutt Tripathi, Charakasamhita, Delhi, Chaukamba Sanskrit Prakashan; 2013.p199

5. Agnivesh, ChikitsaSthana 7:21 Hindi commentary by Acharya Vidyadhar Shukla and Prof Ravi Dutt Tripathi, Charakasamhita, Delhi, Chaukamba Sanskrit Prakashan; 2013.p187

6. Agnivesh, ChikitsaSthana 7:21 Hindi commentary by Acharya Vidyadhar Shukla and Prof Ravi Dutt Tripathi, Charakasamhita, Delhi, Chaukamba Sanskrit Prakashan; 2013.p186

\section{Source of Support: Nil \\ Conflict of Interest: None Declared}

How to cite this URL: Shwetambika et al: Ayurvedic Management Kitibha Kushta W.S.R To Psoriasis - A Sucessful Case Study. International Ayurvedic Medical Journal \{online\} 2021 \{cited May, 2021\} Available from: http://www.iamj.in/posts/images/upload/1147 1151.pdf 